\title{
Dissonâncias estruturais na comunicação do Poder Judiciário no Brasil: perguntas ${ }^{a}$ Structural dissonance in the communication of the Judiciary in Brazil: questions
}

\author{
EUGÊNIO BUCCI ${ }^{b}$ \\ Universidade de São Paulo, Programa de Pós-Graduação em Ciências da Comunicação. São Paulo - SP, Brasil
}

\section{RESUMO}

Este artigo se inscreve no subcampo dos estudos da comunicação pública, em diálogo com as ciências da linguagem. A partir das distinções entre a Ordem do Simbólico e a Ordem do Imaginário, procura levantar questões sobre a comunicação institucional do Supremo Tribunal Federal e sobre a TV Justiça, investigando se é possível compatibilizar a função da Justiça com a função do entretenimento e, especialmente, com o Espetáculo. Ao final, o artigo apresenta breve diagnóstico dos sintomas de desajuste na comunicação do Poder Judiciário no Brasil e propõe diretrizes para que ela seja repensada.

Palavras-chave: Comunicação pública, Simbólico, Imaginário, Poder Judiciário

\begin{abstract}
This article is part of the Public Communication studies, in dialogue with the Language Sciences. From the distinctions between the Symbolic Order and the Order of the Imaginary, it seeks to raise questions on the institutional communication of the Brazilian Supreme Court (Supremo Tribunal Federal) and the TV channel owned by the Brazilian Judiciary (TV Justiça), investigating whether it is possible to combine the function of Justice with the function of entertainment and especially with the Society of Spectacle (according to Guy Debord). Finally, the article presents a brief diagnosis of the symptoms of maladjustment in the communication of the Judiciary in Brazil and proposes guidelines for it to be rethought.
\end{abstract}

Keywords: Public communication, Symbolic, Imaginary, Judiciary 


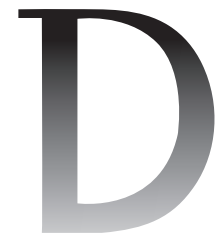

${ }^{1}$ Já apresentei estudos nesse campo em diversas oportunidades. Entre outros, vale lembrar um livro que faz referências diretas à comunicação do Poder Judiciário (Bucci, 2015).
DTE ARTIGO, INSCRITO no campo de estudos da Comunicação 1 Pública ${ }^{1}$, em diálogo com as Ciências da Linguagem, procura questionar e formular perguntas críticas sobre a comunicação do Poder Judiciário no Brasil, tendo como foco principal o Supremo Tribunal Federal (STF), que é a corte suprema da Justiça brasileira. Não se trata de um estudo de caso, ou da análise circunstanciada de uma estratégia de comunicação institucional. Em vez disso, este trabalho parte do mal-estar gerado por impertinências da comunicação do Supremo, sobretudo a partir do uso excessivo de imagens televisivas, para refletir, aí sim, sobre os problemas do diálogo com a sociedade de um poder da República para o qual as distinções do que se convencionou chamar nas Ciências da Linguagem como Ordem do Imaginário e Ordem do Simbólico são cruciais - ou mesmo mortais. Antes de responder, portanto, este artigo pretende interrogar. O questionamento é seu veio de reflexão.

Explica-se: a separação entre o lícito e o ilícito, entre o legal e o ilegal, entre o que a lei consagra e o que a lei veda resulta de operações da linguagem que têm lugar claríssimo na Ordem do Simbólico. É por palavras que a lei se manifesta e é, também, por palavras, que a interpretação da lei se converte, nos tribunais, em decisão judicial. O Judiciário opera, enfim, pela palavra, sendo, por natureza, avesso ao Espetáculo. Aí está, então, o marco inicial da presente reflexão. Se a lei e a Justiça têm parte tão estreita com o Simbólico, o que ocorre com a percepção social da lei e da Justiça quando ambas aderem aos caprichos da tirania da imagem e procuram se emprestar ares de entretenimento, de leveza imagética ou de performance publicitária? Isso não poria em risco a própria função precípua da instituição da Justiça na sociedade contemporânea? Até que ponto a Justiça pode aderir ao Espetáculo?

Façamos outra pergunta, esta mais, por assim dizer, deontológica: até que ponto a Justiça não teria a incumbência de procurar se manter do lado de fora do circo do Espetáculo? Se a indagação merece uma resposta afirmativa - e talvez mereça, ao menos em termos -, deduz-se, então, que o aparato da Justiça e o arcabouço burocrático e institucional do Poder Judiciário teriam que zelar permanentemente para não se deixarem envolver pelas tramas do Imaginário e do Espetáculo, isto é, para não se deixar confundir com a comunicação das imagens espetaculares. A razão dessa cautela é muito simples: ao se deixar absorver - subsumir - pelo Espetáculo, a Justiça talvez perca sua independência de linguagem, ou sua independência de Ordem do Simbólico, e perderia, consequentemente, um dos núcleos de se apresentar à sociedade como um poder capaz de se fazer perceber como poder autônomo.

É claro que, em se tratando de um artigo, o presente texto não esgotará a questão. Longe disso, só o que ele pode almejar é lançar pistas para o 
prosseguimento dessa reflexão necessária. Mesmo assim, preliminarmente, a tentativa há de valer a pena.

Na noite de 30 de novembro, uma sexta-feira, em sua conferência de abertura no Seminário da Feiticeira de 2018, o professor Tércio Sampaio Ferraz Jr. discorreu o tema de fundo do encontro: O papel do Judiciário na democracia atual. O título de sua palestra incluía uma pergunta: "Governo das leis ou governo dos juízes?"2. Dois momentos da introdução feita por ele vão ecoar agora, na contribuição lá apresentada que deu origem a este artigo.

1. O primeiro momento é aquele em que o professor lembrou que vivemos um tempo de superação ou de envelhecimento do espaço demarcado pelo estado-nação. Os pontos concêntricos da opinião pública nacional, ele anotou, estariam em difração. O próprio poder do Estado nacional não é mais o que costumava ser.

2. O segundo momento trouxe questões acerca da comunicação do STF num contexto em que as redes, com base em tecnologias e plataformas digitais, vêm sitiando padrões tecnológicos tradicionais. O professor indagou se "a TV Justiça ficará ultrapassada, se não acossada por essa outra mídia, em meio a uma realidade fragmentária”.

Quanto ao declínio do estado-nação, valeria agregar uma breve nota emprestada de Alain Touraine. Ainda no final do século XX, Touraine (1998) escreveu: "O Estado não está mais no centro da sociedade; está nas fronteiras" 3 (p. 49). Ele tinha em mente a expansão do peso específico da política externa sobre a política interna, em que as negociações diplomáticas e os acertos e desacertos entre países adquire mais centralidade nas esferas públicas nacionais. Seja nas migrações que varrem continentes, seja no fluxo de capitais, que quebra economias nacionais em dois ou três dias, o estado-nação se debate sem êxito. Mais recentemente, a impotência do estado nacional em controlar e regular os monopólios globais dos conglomerados de tecnologia, comércio digital e comunicação apresenta mais um atestado de sua perda de poder. O mesmo poderíamos dizer em face do surgimento das chamadas moedas digitais, que, sem ter qualquer banco central atrás de si, são o dinheiro que não precisa de Estado para valer e para circular.

Além de Touraine, poderíamos lembrar ainda o nome de Octávio Ianni (1998), que, também no final do século XX, detectou o aparecimento do que ele chamou de "sociedade civil global":
${ }^{2}$ Em reportagem publicada no Caderno Ilustríssima, do jornal Folha de S.Paulo, o jornalista Marco Rodrigo Almeida (2019) relatou os principais momentos do seminário.

${ }^{3}$ No original: "El Estado no está más en el centro de la sociedad, sino en sus fronteras". Tradução do autor. 


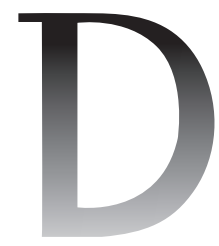

${ }^{4}$ Ver referências ao "cidadão do mundo" na página $107 \mathrm{da}$ mesma obra de Ianni.

${ }^{5}$ Ainda quanto a isso, retomo uma passagem de John Keane (1996), também do final do século XX: "O velho domínio de vida pública limitada territorialmente e estruturada pelo Estado, mediada pelo rádio, televisão, jornais e

livros, está chegando ao fim. Sua hegemonia está sendo rapidamente erodida pelo desenvolvimento de uma multiplicidade de espaços de redes de comunicação, as quais não estão ligadas imediatamente a territórios, $\mathrm{e}$ que por conseguinte flanqueiam e fragmentam qualquer coisa que anteriormente se parecesse com uma esfera pública única e espacialmente integrada dentro da estrutura Estado-nação" (p. 14).
As sociedades contemporâneas, a despeito das suas diversidades e tensões internas e externas, estão articuladas numa sociedade global.... O que começa a predominar, a apresentar-se como uma determinação básica, constitutiva, é a sociedade global, a totalidade na qual pouco a pouco tudo o mais começa a parecer parte, segmento, elo, momento. São singularidades, ou particularidades, cuja fisionomia possui ao menos um traço fundamental conferido pelo todo, pelos movimentos da sociedade civil global ${ }^{4}$. (Ianni, 1998, p. 39)

Temos, portanto, além dos monopólios globais, essa sociedade civil global, que se expande em meio ao enfraquecimento do estado-nação ${ }^{5}$.

Na palestra de abertura, Tércio Sampaio Ferraz Jr. observou que as dificuldades atuais do Judiciário não são brasileiras, mas globais - ou, se quisermos, são dificuldades mundializadas. Ele tem razão. Estamos lidando com fatores estruturais que atravessam ou mesmo que sobrepassam as fronteiras nacionais.

Quanto ao Brasil, a toda hora nos perguntamos: há transparência na comunicação do Poder Judiciário? Ou, mais precisamente, a transparência que existe é suficiente? Pergunta-se também se a cúpula desse poder, ou seja, se o STF não teria ido longe demais a ceder às pressões do poder midiático. Estaria a comunicação do STF sendo negligente com as fronteiras entre o público e o privado? O questionamento se intensifica quando o que está em foco é a TV Justiça. Ela seria por demais espetaculosa? Seria uma comunicação ultrapassada ou inadequada?

O presente artigo não pretende (nem poderia pretender) responder a todas essas indagações. O objetivo é apenas propor uma reflexão sobre o que se entende no Brasil por essa expressão, comunicação do Judiciário, mas num horizonte mais largo ou, por assim dizer, menos tópico, ainda que, ao longo das próximas páginas, não percamos de vista o caso da TV Justiça.

A abordagem adotada aqui, entretanto, evoluirá de modo um tanto digressivo, tangencial, como se se aproximasse do tema pelas bordas. Nessa investida, sintomas aparentemente laterais, acessórios, vão acabar nos interessando - e servindo de rotas de passagem para os aspectos verdadeiramente estruturantes. A essência só se pode tocar por meio das aparências.

De início, ressaltemos as três palavras que tanto nos preocupam no Brasil, quando tratamos da comunicação do Judiciário e, em especial, da comunicação do STF: transparência, público e privado. Da primeira, trataremos logo adiante. Sobre o binômio público-privado, talvez não seja a chave mais fecunda para enfrentar a questão. A dualidade, isto é, a balança pendular apresentada por esse binômio nos conduziria a debates já trilhados. Por isso, em lugar da alternância (ou da promiscuidade) entre as esferas do que é público e do que é privado na 
maneira como o Judiciário se projeta para a esfera pública, seria mais esclarecedor, no caso presente, pensarmos em outra antinomia: aquela que se articula entre duas ordens distintas, quais sejam, a ordem da palavra e a da imagem.

As duas ordens mencionadas - a da palavra e a da imagem - remetem a duas outras ordens que as contêm, a cada uma delas, e que lhes são maiores: a ordem do Simbólico (própria da palavra) e a ordem do Imaginário (própria da imagem). A palavra (como a letra) finca raízes na ordem do Simbólico. Já a imagem - seja ela visual ou representativa, como a tela da televisão ou como um outdoor, seja ela erigida por meio de palavras coladas a sentidos (uma metáfora simples, espontânea na língua vulgar, embora feita de vocábulos, constrói uma imagem de sentido, uma figura de linguagem, e, portanto, devemos pensá-la também como imagem, ou seja, há um efeito de imagem no palavreado corrente) - vai se inscrever na ordem do Imaginário. Em resumo, o Imaginário não se compõe apenas de imagens visuais, aquelas que se entregam ao olhar por fora da mediação do alfabeto, mas incorpora a fala cotidiana e outras modalidades de significação.

Não é objetivo deste artigo aprofundar-se nas conceituações de Simbólico e de Imaginário, que são abundantes na literatura (e não somente na especializada). Passemos então por elas de modo ligeiro, com o único propósito de lembrar que: 1) a função do Simbólico é dada pela lei (em sentido amplo, não jurídico), que, pela linguagem, pelo trânsito ou pelo barramento do significante, marca as diferenças, estabelece as interdições e os limites, lançando as bases regradas que possibilitam nada menos que a civilização ${ }^{6}$; e 2) a função do Imaginário, que também se tece pelos significados que se apresentam como completudes, como sentidos que se bastam nas fantasias de cada um de nós ${ }^{7}$. Crenças, diversões e prazeres psíquicos são mais perceptíveis no domínio do Imaginário, e é aí, precisamente, que a indústria do entretenimento, tão característica da nossa era, comercializa suas infinitas atrações. Vivemos um tempo de imaginário industrializado e, por isso, hipertrofiado.

É possível que, mais que uma hipertrofia, a ordem do Imaginário venha passando por um ciclo em que, além de se expandir, ocupa franjas que estariam originalmente a cargo da ordem do Simbólico ${ }^{8}$. A ser verdade essa desconfiança de que o Simbólico perde espaço para o Imaginário, a função - função da ordem do Simbólico - de marcar os limites às pulsões violentas (dos indivíduos ou do poder) estaria perdendo terreno para a função de afirmação do gozo sem limites, característica do imaginário superindustrial.

Isto posto, voltemos agora à noção de que, no Simbólico, operam a palavra e a letra, enquanto no Imaginário, operam as imagens. O Simbólico interpela o pensamento; o Imaginário interpela o desejo. O Simbólico argumenta, desafia
${ }^{6}$ Uso aqui o termo Simbólico no sentido ordenador que lhe foi dado por Claude Lévi-Strauss (1943/2003): "Toda cultura pode ser considerada como um conjunto de sistemas simbólicos, à frente dos quais se situam a linguagem, as regras matrimoniais, as relações econômicas, a ciência, a arte, a religião" (p. 19). Valho-me, também, dos ensinamentos de um psicanalista arguto, ele mesmo criteriosamente reservado.

${ }^{7}$ A relação entre Simbólico e Imaginário foi pensada por Jacques Lacan, entre outros. Para Lacan, enquanto o Simbólico, pelo significante, barra e interdita, já que diferencia e demarca, o Imaginário seria o plano da identidade com o semelhante, o plano das fantasias do Sujeito. Ver, em especial, as origens de seu pensamento sobre a ordem do Imaginário em Lacan (1998).

${ }^{8}$ Tratei disso em vários trabalhos, entre eles na minha tese de doutorado (Bucci, 2002). Detalhei a produção do valor de gozo na indústria do imaginário em um livro mais recente (Bucci, 2016). 
e conclui, o Imaginário seduz, acaricia e abastece a fantasia. Tomando alguma liberdade (excessiva) com o jogo desses conceitos, talvez seja pertinente supor que o Simbólico acione o Princípio de Realidade formulado por Freud, enquanto o Imaginário destampa e dá novos mandatos ao Princípio do Prazer, também de Freud (Laplanche, 1992, pp. 364-371).

Por certo, o Imaginário não existe sem o Simbólico - e vice-versa. As duas ordens são inseparáveis. São emaranhadas. Com efeito, também, uma não é melhor ou pior do que a outra. Mas, se for pertinente a desconfiança, inerente a este artigo, de que a ordem do Imaginário avança sobre a ordem do Simbólico e, nesta, cumpre as vezes de imperativos superegoicos que, em lugar de interditar, autorizam e divinizam a transgressão, o marco civilizacional enfrenta impasses. Se as coisas são mesmo assim, vale perguntar: qual será o lugar da lei?

Nesses termos, as perguntas que vão se acumulando nestes parágrafos adquirem dramaticidade. $\mathrm{O}$ que temos até aqui? Temos que, em primeiro lugar, a Justiça tem a incumbência de aplicar a lei - tornar a lei parte da vida - e, mais, temos que essa incumbência só pode ser tecida pela palavra (toda sentença judicial é necessariamente uma sentença declaratória, que fixa nomes para as coisas e desses nomes extrai consequências normativas), ainda que só se possa consumar pelo monopólio da força. Se é isso o que temos, levantemos outra interrogação. Poderia a Justiça se comunicar pelas imagens e, mais especificamente, dar-se a ver e a entender pelos repertórios próprios da indústria do entretenimento? Poderia a Justiça se traduzir em imagens e não mais em palavras? Poderia essa tradução não acarretar prejuízos para a própria natureza da Justiça? Será que, ao se deixar seduzir pelo reino das imagens, a Justiça não se perde de sua essência simbólica assim como se perde do rigor com que pronuncia - ou deveria pronunciar - suas palavras?

Fiquemos, por enquanto, com essas interrogações. Antes de respondê-las - e, alerte-se, responder a todas elas ultrapassa as ambições deste trabalho -, fiquemos um pouco mais com as implicações do império da imagem sobre o marco civilizacional em que nos encontramos. A imagem sedimenta o plano em que têm lugar as afecções narcísicas, entre os polos - e aqui fala do que caracteriza a nossa era - do exibicionismo e do voyeurismo. O simbólico, que traria um marcador de impessoalidade mais forte, perde terreno. O neurótico cede lugar para o perverso, dizia a psicanalista gauche.

Há quem fale em civilização da imagem. Régis Debray tocou no assunto. Francês que, após sobreviver ao massacre que se abateu contra a guerrilha de Che Guevara na Bolívia, à qual serviu como voluntário juvenil, Debray (1993) resolveu mudar de vida e achou melhor voltar à França para estudar comunicação. Bom estudioso, disse o seguinte: "Visível = Real = Verdadeiro. Ontologia 
fantasmática da ordem do desejo inconsciente" (p. 354). No mesmo trecho, ele afirma que "somos a primeira civilização que pode julgar-se autorizada por seus aparelhos a acreditar em seus olhos" (p. 354).

Deixemos de lado as palavras ontologia, fantasmática, desejo e inconsciente. Cada uma delas vem rendendo seminários, livros e cursos caudalosos. Falemos um pouco, somente isso, sobre acreditar nos olhos, para assinalar que acreditar nos olhos significa parar de duvidar dos olhos. Acreditar nos olhos é dizer não à Episteme de Platão. Acreditar nos olhos é deixar-se informar apenas pelos sentidos. É renunciar à razão. Acreditar nos olhos é uma forma curiosíssima de cegueira. E isso eu não digo sozinho. O escritor José Saramago, no documentário brasileiro Janela da Alma (Jardim, Tambellini \& Carvalho, 2001), apresenta uma fabulação claustrofóbica:

O que eu acho é que nós nunca vivemos tanto na caverna do Platão como hoje.... Foi preciso passarem todos esses séculos para que a caverna do Platão aparecesse finalmente num momento da história da humanidade, que é hoje. E vai ser, vai ser cada vez mais.

Eis o que significa viver numa civilização que se acredita "autorizada por seus aparelhos a acreditar em seus olhos" (Debray, 1993, p. 354). Segundo outro francês, Guy Debord (1997), o nome dessa civilização não é sociedade da imagem, mas sim sociedade do Espetáculo. Para ele, "toda a vida das sociedades nas quais reinam as modernas condições de produção se apresenta como uma imensa acumulação de espetáculos". Continuando: "Tudo o que era vivido diretamente tornou-se uma representação". E, se quisermos mais, ele nos dá: "o espetáculo não é um conjunto de imagens, mas uma relação social entre pessoas, mediada por imagens" (pp. 13-14).

O que acontece, então, quando a autoridade judicial se comunica pela imagem espetaculosa? Será que uma autoridade judicial, ao integrar-se acriticamente à linguagem imagética do Espetáculo, não reforça a ordem do Imaginário industrializada que traz em si uma renúncia à episteme? Quando a autoridade judicial vai por aí, será que ela não se perde de seu lugar? Será que a autoridade judicial não deveria tentar se distinguir do Espetáculo, que é a ordem do imaginário potencializada pela superindústria cultural, do entretenimento e das tecnologias a seu serviço?

Concedamos que a ninguém neste mundo é possível não ter vínculos com o imaginário superindustrial. Ninguém, nem mesmo o mais circunspecto e reservado dos circunspectos e reservados juízes da Suprema Corte dos Estados Unidos é capaz de não ser lambido pelos tentáculos da imagem. Mesmo assim, 


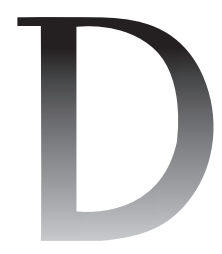

Dissonâncias estruturais na comunicação do Poder Judiciário no Brasil

lambuzar-se nesse melado fosforescente e fluorescente talvez não seja a melhor saída. Um pouco de consciência da ordem do Imaginário espetacular não cairia mal aos magistrados. Não seria descabido se eles tentassem em relação a isso, um distanciamento crítico. Não se trata de um distanciamento pessoal, mas de um distanciamento institucional crítico.

Sigamos adiante, agora com algumas (escassas) considerações sobre a palavra transparência. A ideia de transparência costuma ser invocada como uma vacina (preventiva) ou como um antídoto contra o mal sistêmico da opacidade. Essa ideia nos remete à invenção do Panóptico, por Jeremy Bentham, que depois seria retomado por Foucault (1987), com algumas inversões, e passaria ainda por sucessivas outras inversões, notadamente aquelas precipitadas pelas sucuris de silício da indústria do Imaginário. A engenhosidade do panóptico explicita exatamente a questão da transparência entre governantes e governados, entre vigilantes e vigiados, entre juízes e réus, entre executores e condenados.

Aqui, porém, o substantivo transparência vem a calhar por uma razão singela: ele nos ajuda a distinguir democracia e tirania. Dependendo do vetor da transparência, do lado para o qual aponte esse vetor, teremos uma ou outra. $\mathrm{Na}$ democracia, a gestão dos negócios de interesse público é transparente, enquanto a vida privada (ou íntima) das pessoas tem direito a proteções: é indevassável. Na democracia, a intimidade é inviolável, e nisso se assenta um direito fundamental. Já na tirania temos o oposto (o vetor da transparência muda de sentido): o Estado é opaco, o poder (inclusive o poder não estatal) é opaco, ao passo que a privacidade dos indivíduos pode ser violada a qualquer momento pelo agente que atua em nome do Estado (ou do poder, independentemente da forma conceitual desse poder).

Ora, em nosso tempo, de hipertrofia (possível) da ordem do Imaginário, dá-se um fenômeno deveras intrigante: por ação da massa, as redes sociais tornaram compulsivamente transparentes as paredes das intimidades, e isso por iniciativa um tanto histérica dos sujeitos todos (no que se chama de evasão de privacidade, muito mais frequente que a inocente invasão de privacidade). Por outro lado, o poder dos grandes conglomerados de tecnologia e entretenimento, que são monopólios globais (acima do alcance dos estados nacionais), é perfeitamente opaco: esse poder atua por meio de códigos proprietários, algoritmos secretos, softwares fechados, processos decisórios não compartilhados - todos inalcançáveis pelos cidadãos.

É desconcertante, mas o vetor da transparência parece indicar que vivemos numa tirania. Não levemos ao pé da letra essa pista, claro, pois a ordem mundial é mais complexa do que isso. De todo modo, que algo vai mal nas democracias contemporâneas, isso vai. Para complicar ainda mais o cenário, a acumulação de 
imagens (e de espetáculos) não torna os governos e os poderes mais transparentes. $\mathrm{O}$ que se dá é justamente o contrário. $\mathrm{O}$ excesso de imagens não ilumina, mas ofusca. O excesso de luzes, traduzidas em holofotes que cegam, parece acender um iluminismo paroxístico. As democracias adoeceriam não por escassez de luz, mas por profusões estonteantes de performances ofuscantes.

Se as coisas são assim, vale perguntar: nesse mundo, uma autoridade judicial pode se comportar como um pop star performático, envaidecendo-se das objetivas que a procuram? As vozes se apressam a se declarar comprometidas com a sensatez, inclusive as autoridades que se esbaldam nos palcos iluminados de todas as mídias, diriam que isso não é bom. Mas paremos para pensar. Por que será que no Brasil os ministros do Supremo se converteram em celebridades, em linha de igualdade com jogadores de futebol, atrizes de televisão e socialites? Será que a Justiça pode adotar a linguagem espetacular das celebridades sem que o sentido de sua função democrática se perca no caminho?

É por isso que, mais do que a oposição entre público e privado, a oposição entre palavra e imagem nos interessa de modo mais premente. É preciso falar sobre as aparências. Elas, agora, são tudo - ou quase tudo. É pela aparência que a Justiça se perde de sua essência.

No caso da Justiça, a aparência realiza a essência. É pela aparência, pela simbologia, pela liturgia de seus modos de dizer, de nomear e de ordenar que a Justiça em geral, e o Supremo em especial, cumprirá ou deixará de cumprir seu papel. De que modo o STF poderá atuar como um freio diante da possibilidade de exacerbações do Executivo? A partir de que lugar poderá ser um guardião das liberdades e das garantias fundamentais expressas na Constituição? Com que linguagem e em que plano de representação ele poderá limitar o arbítrio?

Se a Justiça se põe no plano da imagem espetacular de todos os demais agentes da diversão universal, como poderá ser a instância que interrompe o fio interminável das interpretações? Todos sabemos que, para funcionar a contento, essa instância - essa instituição à qual recorrem os que reclamam por justiça - deve guardar alguma reserva, alguma exterioridade em relação à paisagem imaginária generalizada. Todos sabemos disso, mas muitos de nós nos esquecemos. Será que essa exterioridade vem sendo observada pelas autoridades judiciárias? Sua impessoalidade, que só se materializa pelo uso impessoal da palavra - da letra da lei - e pela distância em relação ao totalitarismo da imagem - do imaginário superindustrial - vem sendo realmente observada?

Pensemos agora sobre a TV Justiça, que foi inaugurada em 2002. Perguntemonos: ela aumentou a transparência do Poder Judiciário ou exacerbou as vias de um protagonismo teatral extravagante e inadequado? A TV Justiça é um canal de acesso à Justiça ou um canal a serviço de um jusbonapartismo excêntrico ${ }^{9}$ ?

\footnotetext{
${ }^{9} \mathrm{~A}$ noção de jusbonapartismo é uma categoria que, em parceria com o jornalista Carlos Eduardo Lins da Silva, sugeri num artigo recente (Bucci \& Silva, 2018).
} 
Durante parte da forte inflexão da cúpula do Judiciário brasileiro na direção de se tornar um radiodifusor, ou seja, na direção de atuar na comunicação de massa com equipamentos próprios e frequências exclusivas, $\mathrm{o}$ autor do presente artigo trabalhava em Brasília, como presidente da Radiobrás, e, em 2003, teve ocasião de atender ao então presidente do Supremo, Maurício Corrêa, na montagem de uma emissora de rádio do STF no Distrito Federal, a Rádio Justiça. $\mathrm{Na}$ época, vários dos atores envolvidos no processo consideravam a medida radiofônica e televisiva uma providência acertada, justa e mesmo necessária, posição partilhada por este pesquisador. Com efeito, não era despropositado crer na possibilidade de que seria um percurso didático - especialmente para os juízes, fosse qual fosse o grau de jurisdição de cada um deles. Ao se verem falando para audiências ampliadas, eu supunha, os ministros se sentiriam intimados a ser mais claros. Numa analogia com um certo sabor anedótico, mas não desprovida de sentido, poder-se-ia comparar aquela perspectiva (do ingresso do Judiciário na linguagem da televisão, com vistas a ser bem entendido pelo público) com o Concílio Vaticano II, que, no século XX, representou para a Igreja Católica um fator de simplificação das palavras usadas na missa pelos sacerdotes. Como esses sacerdotes, então, os juízes deixariam de falar Latim e passariam a se esmerar no idioma português.

O tempo passou e, agora, é hora de um balanço. É claro que a TV Justiça abriu janelas novas para que o povo (não nos esqueçamos dessa palavrinha) pudesse mirar mais de perto a atividade judicial. Nessa perspectiva, a TV Justiça cumpriu um papel positivo. Ainda assim, trouxe preocupações graves. Por certo, já se sabia que transmitir ao vivo, em televisão de sinal aberto, as sessões do pleno do Supremo seria um passo de risco. Se ninguém faz isso no mundo inteiro, bem, não era meramente porque nunca tinham tido a ideia. Sim, aquele seria um passo bem arriscado. Logo, eu também sabia que poderiam surgir problemas. Originalidade e ineditismo têm o seu preço. O que sobreveio, porém, é um quadro extremamente preocupante.

O advogado Márcio Thomaz Bastos, que foi ministro da Justiça no primeiro mandato de Lula (o mesmo período em que trabalhei em Brasília, para o mesmo governo), era terminantemente contra pôr no ar, ao vivo, as sessões do Supremo. Sobretudo em matéria penal. Ele era contra e foi contra até o fim da vida. Depois, quase que resignado, ele diria que não dava mais para voltar atrás. O Brasil teria de aprender a conviver com o Supremo no horário nobre, mas teria que trabalhar para reduzir os danos. Quanto ao autor deste artigo, que achava que a TV Justiça contribuiria para elevar o grau de transparência das instituições, agora tem dúvidas: tem as antigas, que deveria ter antes, mas não tinha, e tem também as novas, que não 
poderiam ter sido previstas antes, como não o foram. Às vezes, fica no ar a sensação de que as vaidades performáticas subiram a cabeça dos meritíssimos, de qualquer instância. Todos se sentiram instados a sair por aí dando entrevistas, aparecendo em revistas de colunismo social, a frequentar talk shows quando vai alta a madrugada. Realmente tenho dúvida. O que venceu, afinal, a transparência ou a estridência?

Em um ótimo artigo sobre a TV Justiça, o advogado e doutor em Direito pela Faculdade de Direito da USP, Luiz Armando Badin (2018), apontou com ponderação e sensatez as distorções provocadas pela altíssima visibilidade dos ministros do Supremo. São elas:

a. desgaste da imagem do tribunal;

b. incentivo à afirmação de posições individuais, em detrimento do colegiado;

c. prejuízo ao debate espontâneo e à qualidade da fundamentação das decisões;

d. espetacularização do julgamento;

e. abuso da retórica;

f. inibição do papel de afirmar direitos constitucionais mesmo contra a vontade da maioria ou das correntes predominantes de opinião;

g. prejuízo à independência e à impessoalidade;

h. aumento do tempo dos julgamentos;

i. exposição excessiva dos réus, em detrimento da sua dignidade.

De nossa parte, acrescentamos a essa lista três perturbações que abalam a função primeira da autoridade judicial, não apenas no âmbito do Supremo:

a. Os desentendimentos públicos entre magistrados, ao vivo, muitas vezes com ofensas pessoais, durante sessões do pleno da corte, além de conspurcar a reputação da corte, concorrem para exacerbar o personalismo que, no limite, é incompatível com a função de julgar; 
b. Os transbordamentos de opiniões pessoais dos juízes sobre assuntos diversos, às vezes sobre temas indiretamente conectados a casos que aguardam julgamento, também concorrem para sabotar o princípio da impessoalidade, além de reforçar uma aura de celebridade em torno das autoridades do Judiciário;

c. Nesse sentido, a banalização de manifestações fora dos autos sobre temas que serão objeto de julgamento, ou que estão em julgamento, arranham a confiabilidade do processo judicial.

Quando se entrega aos prazeres narcísicos da comunicação de massa - ou, se preferirem, quando enveredam dos labirintos do deleite gozoso proporcionado pelas redes sociais e suas variantes que produzem celebridades para o consumo das massas ou das tribos - a autoridade judicial ganha fama e perde nada menos que... autoridade.

Tudo está implicado. Tudo, até mesmo a toga. Reflitamos, por um minuto, sobre essa vestimenta. Marca daquilo que risca uma linha divisória entre, de um lado, o corpo de um ser humano em particular, e, de outro, o ato de julgar (ato que representa não a pulsão do corpo mas a vontade da lei), a toga, a triste toga, até ela, vem mudando de aspecto, de figura e de imagem. Antes um dispositivo de ocultamento, um traje que tirava de cena o corpo do juiz para, em seu lugar, instalar a figura impessoal do juiz, a toga, que foi redesenhada ao longo das décadas, parece, agora, um adereço de super-herói. Nesse ponto, recorramos à reportagem assinada pela jornalista Gisele Vitória (2018), para a Revista de

${ }^{10} \mathrm{~A}$ relação entre a toga e a capa, sugerida por mim, foi brilhantemente aprofundada por Gisele Vitória (2018) numa retrospectiva que explora, no curso histórico, a simbologia das vestes talares. Jornalismo ESPM, a partir de uma pauta elaborada pelo autor do presente texto ${ }^{10}$. A toga não barra a vaidade pessoal. Ao contrário, emoldura o corpo adornado, acentuando, aí, as veleidades narcísicas. Hoje, a toga se comporta não como indumentária austera, mas como uma capa, um enfeite de Zorro, de Batman, ou, pior ainda, de Darth Vader. A toga flana.

Alguns envergam a toga, prendem com a mão a sua barra lateral e, quando movem o braço para frente, bem esticado, fazem com que ela se desfralde como bandeira, num balé supremo. No imaginário popular (e voltamos ao Imaginário) ali está o traje não de um árbitro isento, mas de um vingador. Ali está não um signo da Justiça, cega, altiva, inabalável, livre de paixões, mas o signo da impetuosidade redentora.

A toga que era um travo contra a vaidade humana, um limite contra individualismos extremados, um componente simbólico e disciplinador essencial para um ambiente em que a vaidade não tem assento, vai aos poucos se convertendo num enfeite para desfiles de linhas esvoaçantes. As togas se prendem 
nos ombros dos ternos dos ministros por tiras finíssimas que parecem alças de biquíni. As alças ficam visíveis. Os ministros do STF, data venia, sem nenhuma teratologia, trajam suas togas como se elas fossem insígnias de justiceiros destemidos. Passeiam confiantes sob os holofotes do Espetáculo e sob a brisa do Brasil, aquela mesma que, encontrando um tecido leve pela frente, à sua trama beija e balança.

Vaidade, imagem, narcisismo, exibicionismo: afecções imaginárias da civilização. O que fazer? Por certo a resposta não é simples. Não obstante, poderíamos, com espírito desarmado, arriscar sugestões.

A cúpula e o corpo integral do Judiciário brasileiro deveriam elaborar e desenvolver um entendimento mais denso sobre o que significa agir como reserva da razão na democracia. Deveriam refletir sobre a arquitetura invisível do Simbólico que abriga a lei. Deveriam meditar sobre os nexos do Simbólico com o plano material dos fatos humanos, os fatos que vertebram nossas biografias insignificantes. Deveriam se dedicar a compreender os desígnios do pensamento que fazem da palavra o registro insubstituível da concepção e da expressão da Justiça.

Nesse nível, o modo como a Justiça se expressa não deveria ser planejado num plano distinto daquele em que a Justiça proclama suas decisões. A comunicação da Justiça não deveria ser um departamento separado da própria Justiça. Ao contrário, a comunicação da Justiça só tem sentido como um prolongamento do modo de ser da Justiça. Feita de palavras e não de imagens, a Justiça, impessoal e não personalista, é clara por ser justa no coração dos homens e das mulheres, e não por ser desinibida. Ela só se pode dar a entender quando é o que é. Quando, simplesmente, é. A Justiça só aparece quando o julgador se exime de mostrar-se. O julgador que aparece no lugar da Justiça a ofusca.

Em conclusão, oferecemos cinco pequenas propostas para aqueles que, tocados pelo tema, sintam-se inclinados a dedicar-lhe atenção.

1. Agir pela palavra, nunca se exibir pela imagem. Quando for irreversivelmente necessário se manifestar fora dos autos, uma circunstância ultraexcepcional, o juiz deveria evitar performances diante das câmeras.

2. Reduzir o contato com a imprensa, não para sonegar-lhe a informação que o cidadão tem direito de receber, mas para fazer refluir o efeito celebridade que acomete os homens e as mulheres incumbidos de julgar. Juiz só deve ser notícia quando se desvia. No mais, não lhe seria recomendável sair de trás de sua toga (o juiz atrás da toga 
planta os pés no Simbólico; a toga atrás do juiz, desfraldada em capa, projeta-o para o Imaginário).

3. Fortalecer a identidade coletiva das cortes, o que se faz pela comunicação, menos pelas opiniões particulares e pelos estilos pessoais de magistrados, e mais por aquilo que se instaura como resolução impessoal, como expressão da instituição.

4. Fortalecer a referência do colegiado, em proveito de um padrão jurisprudencial mais nítido e eficaz, o que requer inibir o impulso expansivo das manifestações individuais.

5. Estabelecer um pacto, nos colegiados, para que as divergências entre os julgadores, que são naturais, cessem de uma vez por todas de se ostentar como disputas sangrentas num reality show ao vivo. A Justiça, quando tarda, falha. Quando se apressa em dar espetáculo, também.

Como se vê nas sugestões apresentadas, não há distinção entre a solução institucional para os impasses do Judiciário e a solução que alguns acreditam ser um mero acerto de comunicação. O problema de comunicação do Judiciário não é, no fundo, um problema de comunicação. É antes um problema da instituição de sua finalidade, de seus princípios e de sua administração. A comunicação da Justiça deve ser concebida como o prolongamento da Justiça, não como um enxerto de marketing sobre o organismo simbólico da Justiça. Nada mais simples.

No mais, as coisas ainda podem piorar. No dia em que os ministros do Supremo aderirem a essa mania de ter conta no Twitter, como já o fazem Trump, Bolsonaro e apresentadores de programas de auditório, o que já não anda bem terá piorado.

Por fim, restam ainda indagações sobre a TV Justiça. Deveria ela ser eliminada? Como observa uma voz interlocutora da elaboração deste artigo, há o fato de que a TV Justiça, assim como os demais veículos de televisão estatal e da televisão pública em geral, raramente ultrapassa o traço de audiência. Os cofres públicos deveriam insistir nesse tipo de divulgação? Ou seria mais produtivo uma central do STF que gerasse imagens para serem distribuídas - como já acontece - pelos veículos de TV aberta, TV por assinatura e canais de internet que reproduzem, editam, comentam e agregam interpretações a seu conteúdo. Fora isso, quando considerada como um canal autônomo, não estaria a TV Justiça aprisionada por estratégias pessoais ou corporativistas de visibilidade propagandística, nos moldes descritos, em tons críticos, pelo presente texto? 
Voltemos agora a uma interrogação apresentada ainda nos primeiros parágrafos deste artigo: a Justiça não teria a incumbência de procurar se manter do lado de fora do circo do Espetáculo? Quer nos parecer que a resposta afirmativa se impõe. Sim, entre as muitas atribuições do Poder Judiciário e, de modo especial, do STF, deveria estar aquela de zelar, ininterruptamente, para que os seus representantes - magistrados de todas as instâncias - não se confundam com agentes públicos políticos que disputam espaço na arena do debate público mediado pelas linguagens da publicidade. A autoridade da Justiça é tanto mais forte quanto mais ela se assenta no registro da palavra, na ordem do Simbólico.

Outro aspecto a sublinhar, à guisa de conclusão, seria o imperativo da impessoalidade em suas relações com o processo midiático implicado na instância comunicacional da TV Justiça. Com efeito, há que se observar que há, aí, uma incompatibilidade de frequências ou de registros comunicacionais: ou bem o magistrado, especialmente os ministros do Supremo, abrem mão do estrelato nos termos da indústria do entretenimento, do imaginário superindustrial ou do Espetáculo, fazendo valer suas decisões por meio da palavra da lei traduzida em decisões legítimas, legalmente fundamentadas e impessoais, quer dizer, decisões em que o fator da autoria é contingência lateral e não central, ou bem a Justiça se apequena dentro da feira de vaidades que estabelece o denominador comum do imaginário na era do Espetáculo. É nesse sentido que o imperativo da impessoalidade, de resto já contemplado nas páginas anteriores, apresenta-se para a Justiça, como um anteparo que atua em sentido contrário ao Espetáculo. $\mathbf{M}$

\section{REFERÊNCIAS}

Almeida, M. R. (2019, 12 de janeiro). "É hora de o Judiciário se recolher", afirma Dias Toffoli em casa de praia. Folha de S.Paulo. Recuperado de http://bit.ly/2NoGxcy

Badin, L. A. (2018). Qual é a justa medida da publicidade dos julgamentos? Revista de Jornalismo ESPM, 7(22), 18-21.

Bucci, E. (2016). A forma bruta dos protestos: Das manifestações de junho de 2013 à queda de Dilma Rousseff em 2016. São Paulo, SP: Companhia das Letras.

Bucci, E. (2015). O Estado de Narciso: A comunicação pública a serviço da vaidade particular. São Paulo, SP: Companhia das Letras.

Bucci, E. (2002). Televisão objeto: A crítica e suas questões de método (Tese de doutorado de Comunicações e Artes, Universidade de São Paulo, São Paulo, SP, Brasil).

Bucci, E., \& Silva, C. E. L. (2018). O jusbonapartismo contra a imprensa. Revista de Jornalismo ESPM, 7(22), 12-17. 
Debord, G. (1997) A sociedade do espetáculo. Rio de Janeiro, RJ: Contraponto. Debray, R. (1993). Vida e morte da imagem. Petrópolis, RJ: Vozes.

Foucault, M. (1987). Vigiar e punir: Nascimento da prisão (27a ed.). Petrópolis, RJ, Vozes.

Ianni, O. (1998). A sociedade global (6a ed.). Rio de Janeiro, RJ: Civilização Brasileira.

Jardim, J. (Produtor \& Diretor), Tambellini, F. R. (Produtor), \& Carvalho, W. (Diretor). (2001). Janela da alma [filme cinematográfico]. Rio de Janeiro, RJ: Tambellini Filmes e Produções Audiovisuais.

Keane, J. (1996). Transformações estruturais da esfera pública. Comunicação \& Política, 3(2), 6-29.

Lacan, J. (1998). O estádio do espelho como formador da função do eu. In J. Lacan, Escritos (pp. 96-103). Rio de Janeiro, RJ: Jorge Zahar.

Laplanche, J. Vocabulário da Psicanálise / Laplanche e Pontalis. São Paulo, SP: Martins Fontes, 1992.

Lévi-Strauss, C. (2003). Introdução à obra de Marcel Mauss. In M. Mauss, Sociologia e Antropologia (pp. 11-46). São Paulo, SP: Cosac Naify. (Obra original publicada em 1943)

Touraine, A. (1998). Comunicación política y crisis de la representatividad. In J.-M. Ferry \& D. Wolton, El nuevo espacio publico (2a reimpr., pp. 47-56). Barcelona, Espanha: Gedisa.

Vitória, G. (2018). A toga e a capa. Revista de Jornalismo ESPM, 7(22), 26-29.

Artigo recebido em 2 de fevereiro de 2019 e aprovado em 26 de julho de 2019. 